\title{
The Inter-American System and Women's Rights
}

\author{
Author \\ Ciara O'Connell, $\mathrm{PhD}$ \\ Postdoctoral Fellow \\ Centre for Human Rights \\ University of Pretoria \\ ciaramoconnell@gmail.com \\ www.ciaraoconnell.com
}

\begin{abstract}
The Inter-American System of Human Rights has proven itself to be a forum for the advancement of women's rights. From developing the first women's rights treaty specifically designed to address violence against women, to issuing reparations that require states to prevent gender discrimination, the Inter-American System has increasingly led the way in promoting a women's rights lens to examine international human rights law. While its efforts to uncover the causes of women's rights violations may fall short at times, the jurisprudence emerging from the Inter-American System of Human Rights provides lessons on how, and how not to, develop women's rights litigation. This chapter provides an overview of the regional system's women's rights convention (the Convention of Belém do Pará), highlights notable advancements in developing women's rights in the Inter-American region, and discusses several landmark women's rights cases recently decided by the Inter-American Court of Human Rights. It concludes by looking forward to the Inter-American System's upcoming challenges and opportunities for advancing women's rights in the region.
\end{abstract}

Keywords: Inter-American Human Rights System; Regional Human Rights Systems; Women's Rights Litigation

\section{INTRODUCTION}

Within the last decade, the Inter-American System of Human Rights (IASHR) has made significant progress in its efforts to define, interpret, and repair the gendered nature of women's human rights violations. Despite the limited number of women's rights cases to come before the Inter-American Commission on Human Rights (the Commission) and the Inter-American Court of Human Rights (the Court), the IASHR has been at the forefront of developing a women's rights agenda. This chapter provides an overview of the work of the IASHR work on gender and women's rights; particularly focusing on the region's women's rights convention and jurisprudence. In addition to introducing women's rights in the IASHR, this chapter also raises critiques about the capacity for this regional human rights system to effectively take account of, prevent, and repair violations of women's rights. 
This chapter consists of three parts: the first, outlines the IASHR's women's rights convention, the Convention of Belém do Pará (1994), and highlights its specific attributes, shortcomings, and strategies for its use in litigation. The second discusses landmark women's rights jurisprudence emerging from the Court. Finally, the third and concluding section draws attention to areas where the IASHR could more effectively advance a women's rights agenda.

\section{THE EVOLUTION OF WOMEN'S RIGHTS IN THE INTER-AMERICAN SYSTEM}

The IASHR has increasingly been recognized as a forum for the advancement of women's human rights. Over the past two decades, the Commission issued precautionary measures, made recommendations in women's rights cases and published numerous reports on women's rights issues (Inter-American Commission on Human Rights n.d.c, n.d.a). The Court has ordered judgments in cases concerning femicide (feminicidio) and reproductive health, as well as issued provisional measures to protect the lives of women (Inter-American Commission on Human Rights n.d.b). There is a noted increase in women's rights petitions submitted to the Commission over the past ten years, however, advancing a genderperspective through the IASHR's activities has been gradual and inconsistent (Celorio 2014). This first section introduces the IASHR treaty monitoring bodies and provides an overview of the region's women's rights convention - the 1994 Inter-American Convention on the Prevention, Punishment and Eradication of Violence against Women (Convention of Belém do Pará). In addition, this section includes an introduction to women's rights advancements in the IASHR, such as the integral role of civil society before the Commission and feminist expansion of the principle of due diligence.

\section{Defining Women's Rights}

The IASHR exists within the Organization of American States (OAS) and is the regional human rights system dedicated to the purposes of advancing democracy, human rights, security and development in the Americas (OAS n.d.b). The IASHR entrusts two treatymonitoring bodies with protecting, promoting, and fulfilling human rights in the American hemisphere: the Inter-American Commission on Human Rights and the Inter-American Court of Human Rights. The Commission and the Court share the mission of advancing human rights in the region, but their duties, responsibilities, jurisdiction and powers of enforcement vary significantly. Each body operates using rules of procedure that outline the working relationship and activities of the Commission (OAS 2013) and the Court (OAS 2009). The Commission admits cases; issues precautionary measures; oversees Friendly Settlement Agreements (FSAs) arranged by petitioners and states; develops Merits Decisions in situations where states fail to engage in FSA processes; investigates and reports on specific countries and thematic areas; monitors state compliance with OAS treaties and reparations; and recommends cases to the Court (Pasqualucci 2013). Whereas FSAs and Merits Decisions before the Commission are non-binding in nature, litigation before the Court results in binding judgments. However, only those states that have accepted the jurisdiction of the 
Court are bound to its rulings. (The current list of signatories and ratifications is available via the OAS website.) The Court also prepares advisory opinions and provisional measures to protect persons (Burbano-Herrera 2015).

The American Convention on Human Rights (ACHR), which was drafted in 1959, and became the Inter-American region's principal human rights treaty in 1969, created the Commission and the Court (ACHR, art 33). The ACHR is dedicated to protecting and promoting traditional civil and political human rights, such as the right to life (art 4); the right to humane treatment (art 5); the right to privacy (art 11); and freedom of religion (art 12). The OAS adopted numerous other human rights treaties, including the Protocol of San Salvador which delineates economic, social and cultural rights, and the world's first women's rights convention designed to address violence against women, the Convention of Belém do Pará (OAS n.d.a).

The Convention of Belém do Pará can be understood as an elaboration of the ACHR. It entered into force in March 1995, just nine months after opening for signature deposits. It is the most ratified treaty in the IASHR, with only the United States, Canada, and Cuba withholding their ratification deposits. The Convention of Belém do Pará defines violence against women as 'any act or conduct, based on gender, which causes death or physical, sexual or psychological harm or suffering to women, whether in the public or private sphere. (art 1). Feminist discourse permeates the Convention of Belém do Pará text; for example, the Preamble states, 'violence against women is an offense against human dignity and a manifestation of the historically unequal power relations between men and women'. The Convention confronts violence against women in both the private and public spheres and demands that violations of women's rights be justiciable before the Commission and the Court.

Although the Convention of Belém do Pará represents a positive advancement for women's human rights within the IASHR, at this point in its application, only Article 7 falls under the jurisdiction of the Commission and the Court as indicated in Convention of Belém do Pará Article 12. Article 7 requires that:

States Parties condemn all forms of violence against women and agree to pursue, by all appropriate means and without delay, policies to prevent, punish and eradicate such violence and undertake to:

a. refrain from engaging in any act or practice of violence against women and to ensure that their authorities, officials, personnel, agents and institutions act in conformity with this obligation;

b. apply due diligence to prevent, investigate and impose penalties for violence against women;

c. include in their domestic legislation penal, civil, administrative and any other type of provisions that may be needed to prevent, punish and eradicate violence against women and to adopt appropriate administrative measures where necessary; 
d. adopt legal measures to require the perpetrator to refrain from harassing, intimidating or threatening the woman or using any method that harms or endangers her life or integrity, or damages her property;

e. take all appropriate measures, including legislative measures, to amend or repeal existing laws and regulations or to modify legal or customary practices which sustain the persistence and tolerance of violence against women;

f. establish fair and effective legal procedures for women who have been subjected to violence which include, among others, protective measures, a timely hearing and effective access to such procedures;

g. establish the necessary legal and administrative mechanisms to ensure that women subjected to violence have effective restitution, reparations or other just and effective remedies; and

h. adopt such legislative or other measures as may be necessary to give effect to this Convention.

The Commission and the Court are limited to the singular application of Article 7 of the Convention of Belém do Pará because of the limitations the Convention imposes on the application of its own provisions. Article 12 of the convention states that petitioners 'may [only] lodge petitions with the Inter-American Commission on Human Rights containing denunciations or complaints of violations of Article 7 of this Convention by a State Party.' However, the Court has determined that in addition to Article 7, 'the different Articles of the Convention of Belém do Pará may be used to interpret it and other pertinent Inter-American instruments', which include Articles 8 and 9 of the Convention (Gonzalez et al. 'Cotton Field' v. Mexico 2009, para 79).

The Convention of Belém do Pará Article 8 is fundamental to the eradication of violence against women and the promotion of women's human rights. Article 8 includes protections such as:

The States Parties agree to undertake progressively specific measures, including programs:

a. to promote awareness and observance of the right of women to be free from violence, and the right of women to have their human rights respected and protected;

b. to modify social and cultural patterns of conduct of men and women; including the development of formal and informal educational programs appropriate to every level of the educational process, to counteract prejudices, customs and all other practices which are based on the idea of inferiority or superiority of either of the sexes or on the stereotypes roles for men and women which legitimize or exacerbate violence against women;

c. to promote the education and training of all those involved in the administration of justice, police and other law enforcement officers as well as other personnel responsible for implementing policies for the prevention, punishment and eradication of violence against women. (Convention of Belém do Pará, art 8) 
Although the Court has determined it does not have jurisdiction over Article 8 of the Convention of Belém do Pará, it can be argued that Article 7 cannot be fully understood, nor implemented, if not interpreted through the lens of Article 8. Furthermore, Article 9 provides a fundamental and overarching understanding of the situation within which Articles 7 and 8 exist:

With respect to the adoption of the measures in this Chapter, the States Parties shall take special account of the vulnerability of women to violence by reason of among others, their race or ethnic background or their status as migrants, refugees or displaced persons. Similar consideration shall be given to women subjected to violence while pregnant or who are disabled, of minor age, elderly, socioeconomically disadvantaged, affected by armed conflict or deprived of their freedom. (Convention of Belém do Pará, art 9)

By designating and defining women's position as vulnerable, Article 9 demands that provisions outlined in Article 7 be implemented with a view to protecting women's rights despite their socially and culturally defined status as unequal to men. In addition, Article 9 takes into account the intersectional and compound nature of violence as it disproportionately impacts marginalized and disenfranchised communities (Mohanty 2003; Crenshaw 1989, 1991).

Women's rights violations enshrined within the Convention of Belém do Pará have increasingly been alleged and determined in litigation before the Commission and the Court. However, the Convention also provides impetus for investigating and reporting carried out by the Special Rapporteur on Women's Rights. Recent reports include themes such as Access to Justice for Women Victims of Sexual Violence (Rapporteur on the Rights of Women 2011b) and Access to Information on Reproductive Health from a Human Rights Perspective (ibid.). In 2004, the OAS established The Committee of Experts of the Follow-up Mechanism to the Belém do Pará Convention, which is 'a system of consensus-based and independent peer evaluation to assess the progress made by [a] States Party in their fulfilment of the objectives of the Belém do Pará Convention' (MESECVI 2012). The objective of this OAS body is to 'follow through with the commitments undertaken by the States Party to the Convention, to help accomplish its stated purposes, and to facilitate technical cooperation among the States [Parties].' While MESECVI is an OAS entity designed to work alongside the Commission and the Court, thus far there is no clear collaboration forged between the three bodies.

This overview of the IASHR's Convention of Belém do Pará provides a glimpse into the women's rights legal framework in the Inter-American region. Notably, the Convention itself is formulated in such a way that it is difficult to pin point and define clear rights. Whereas the ACHR delineates rights such as the right to privacy (art 11), the Convention of Belém do Pará is worded in such a way that it is difficult for advocates and activists to build quick concise arguments and links with rights enshrined within the ACHR. This critique is raised here to draw attention to the challenges inherent in developing a treaty that at once encompasses a gender perspective and also fits within the 'normal' way of defining and articulating rights. While the Convention of Belém do Pará is certainly formative in outlining 
women's rights within the 'violence against women' rubric, perhaps the most novel and interesting components of women's rights protections in the IASHR can be found in feminist and civil society efforts to push out the boundaries of the Convention.

\section{MAKING PROGRESS: ADVANCING A FEMINIST RIGHTS PERSPECTIVE}

In that the Convention of Belém do Pará locates women's rights within a violence against women framework, it creates space for women's rights advocates to flesh out the gendered nature of women's rights violations and expand upon state requirements to prevent violence. This section introduces two innovative approaches employed by advocates working within and outside of the IASHR to strengthen women's rights protections enshrined within the Convention of Belém do Pará.

\section{Institutionalizing Women's Rights Civil Society}

The IASHR and civil society organizations share a mutually supportive relationship. Civil society organizations may refer to the IASHR to enforce individual rights, yet the IASHR depends on civil society participation to support its legitimacy (OAS 1999; Cavallaro and Schaffer 2004). Civil society contributes to the activities of the IASHR by representing victims, providing information through thematic hearings and human rights reporting, and monitoring reparations in the compliance stages of Friendly Settlements, Merits Decisions and Court judgments (OAS 2013, art 23; OAS 2009, art 25). The Commission and the Court incorporate contextual information provided by civil society organizations within their work, and also rely on civil society organizations to monitor state compliance. However, despite their significant monitoring role, civil society organizations do not contribute to the design of reparations. In order to understand how women's rights civil society organizations became integral to the work of the IASHR, it is beneficial to briefly examine how the Latin American women's rights movement evolved to incorporate a rights-based agenda that included participation in international human rights institutions.

Feminist activism in Latin America has historically focused on the development of meaningful citizenship as a part of the struggle for democracy (Tolentino 2014). Advancing women's citizenship through empowerment was, and is, one of the primary tasks of Latin American women's rights organizations. However, since the 1980s and 1990s, Latin American women have become particularly active and influential throughout international human rights arenas. Feminist and women's rights movements began to use international human rights instruments in education campaigns to inform women and men about their rights, and actors began using international agreements to hold governments accountable and push for national policy and legislative reform (Craske and Molyneux 2002). In the 1990s, a human rights agenda came to the fore, where the 'focus shifted to questions of how rights can be incorporated into general questioning of women's place in their own societies' (Craske and Molyneux 2002). Significantly, this era saw the beginning of the 'institutionalization of feminism' across Latin America. This is an ongoing process as more organizations 
familiarize themselves with and utilize international mechanisms to inform women and men about their rights, as well as to challenge states that fail to prevent, protect and fulfil rights. However, as women's rights organizations have become more focused on institutional engagement, there exists the risk that they will move away from their local and nationallyfocused agendas and contexts (Vargas 2002).

The intentional decision on the part of women's rights and feminist civil society organizations to engage with the IASHR increased the number of women's rights-focused petitions submitted to the Commission and informed the investigative work of the Rapporteur on the Rights of Women (Inter-American Commission on Human Rights n.d.a). In many of the cases dealing with violations of women's rights, it is national and international women's rights organizations, often working in collaboration, which represent victims. For example, the US-based international legal NGO, the Center for Reproductive Rights partnered with Costa Rican NGO, La Colectiva, to raise a petition on abortion access before the Commission (Center for Reproductive Rights 2013). While feminist actors across Latin America raise valid concerns about dedicating limited resources to the project of institutionalizing feminism in supranational human rights bodies, it is undeniable that civil society participation has been integral to establishing a feminist agenda within the activities of the Commission and the Court.

\section{Expanding Due Diligence}

The concept of due diligence, outlined in Article 7(b) of the Convention of Belém do Pará, requires states to 'prevent, investigate and impose penalties for violence against women.' In that the Commission and the Court may only determine violations of Article 7 of the Convention, feminists have worked to expand the requirement to prevent violations so that it includes state duties to confront the causes of gendered violence; including discrimination, gender stereotyping, and harmful cultural practices. Elizabeth A.H. Abi-Mershed, Assistant Executive Secretary of the Commission explains due diligence as it is protected within the Convention of Belém do Pará:

The Convention of Belém do Pará requires that states parties ensure that their agents refrain from acts of violence against women, and further requires that these states apply due diligence to prevent, investigate and punish such violence when perpetrated by non-state actors in the home, community or wherever it may occur. (Abi-Mershed 2009, 131; emphasis added)

Abi-Mershed argues that the due diligence standard serves the IASHR as a 'flexible way of understanding what state obligation and responsibility mean in theory, and more importantly, in practice' (Abi-Mershed 2009). Further to this, Paulina García-Del Moral and Megan Alexandra Dersnah note that the application of Article 7(b) in women's rights cases allows feminists to 'strategically challenge the gendered politics of the public/private divide underlying the historical depoliticization of violence against women that, until recently, had shielded the state and international human rights law' (García Del-Moral and Dersnah 2014). 
Finally, Liz Melendez, Executive Director of Peruvian feminist NGO, Flora Tristan, echoes this analysis by claiming that the obligation for states to prevent women's rights violations effectively requires states to prevent structural violence and discrimination, wherever and however it may originate. She argues that the most practical and effective strategy in women's rights litigation is to locate women's rights within civil and political, or 'universal' rights, such as due diligence (Melendez 2014). The power of the due diligence provision cannot be underestimated, especially because this principle politicizes violence occurring in the private sphere, and therefore disrupts traditional notions surrounding negative and positive state obligations to prevent, protect, and fulfil human rights.

The footprint of feminist civil society and internal individual efforts to engender human rights law are noticeable in the Court's jurisprudence, as well as in the Commission's reporting, decisions, and FSAs. However, practitioners familiar with the IASHR underline that it is not a feminist institution, and any gains made in advancing a gender-perspective through the IASHR are reliant on individual actors; there is no internal agenda to institutionalize gender in the IASHR (Celorio 2014; Cardenas 2014). That being said, feminist appropriation of the due diligence principle coupled with the institutionalization of feminist civil society within the IASHR, provides innovative strategies for reconceptualizing the IASHR's approach to defining and interpreting human rights law. The following section examines notable IASHR women's rights cases; particularly those from the Court, as these cases are binding and reveal advancements and missed opportunities in developing women's rights within the regional system.

\section{LITIGATING WOMEN'S RIGHTS: INTER-AMERICAN COURT JURISPRUDENCE}

The Court has issued judgments in ten women's rights cases (Inter-American Commission of Human Rights n.d.b). However, it can be argued that the Court has neglected to incorporate a gendered analysis of rights violations in cases concerning women on a number of occasions (Palacios Zuloaga 2008). The cases selected for discussion in this chapter were chosen because they represent landmark moments in the Court's analysis of gender as a contributing characteristic to gender-based stereotyping, violence against women, and restrictions on women's health access.

\section{Case 1: González et al. ('Cotton Field’) v. Mexico (2009)}

In this case, the Court ruled that the state of Mexico had violated both the ACHR and the Convention of Belém do Pará when it failed to prevent and investigate the disappearance and murder of three poor migrant women. The Court emphasized that these murders were representative of hundreds of disappearances, rapes, and murders that were poorly investigated by the State of Mexico. This was the first case in which the Court formally developed its jurisdiction over Article 7 of the Convention of Belém do Pará, and it was also the first time that the Court determined that states have a positive obligation to respond to 
violence against women resulting from the actions of private actors, and that those violations are justiciable under Article 7 of the Convention of Belém do Pará. In addition, the Court adopted the term 'femicide' (feminicidio) to refer to the killing of women because they are women, and determined that states have an obligation to ensure due diligence through 'education and training programs and courses for public officials on human rights and gender [...] and judicial proceedings concerning gender-based discrimination, abuse and murder of women, and to overcome stereotyping about the role of women in society' (Gonzalez et al v. Mexico 2009, para 602(22)). This case is the foundational women's rights case in the IASHR because it set precedent for application of the Convention of Belém do Pará Article 7, and also established practice that would allow the Court to interpret Article 7 through the lens of Articles 8 and 9 of the Convention.

Case 2: Artavia Murillo et al. ('In Vitro Fertilization') v. Costa Rica (2012)

The Artavia Murillo et al. v. Costa Rica case challenged Costa Rica's ban on in-vitro fertilization. The judgment issued by the Court in this case was both ground-breaking and disappointing for a number of reasons. This was the first reproductive health rights case to come before the Court, and it was also the Court's first opportunity to examine the right to life as it applied to 'the unborn'. Not only did the Court assert that the right to life as enshrined in Article 4(1) of the ACHR should not be considered absolute when its protections 'justify the total negation of other rights,' but the Court also thoughtfully examined the gendered implications of stereotyping as it relates to women and men who are unable to conceive children.

Despite the advancements made in this case in relation to future efforts to advocate for women's reproductive freedom, it ultimately fell short as a women's rights case. First, civil society organizations were blocked by lawyers from participating in the case because of concerns that the case may be linked with the abortion rights movement. Instead the petitioners elected to distance the case from issues of reproductive freedom and women's rights and developed their argument through a reproductive disability lens (Alejandra Cardenas 2014; Artavia Murillo et al. v. Costa Rica 2012). As a result, the Court declined the petitioner's efforts to allege a violation of the Convention of Belém do Pará, and subsequently neglected to issue reparations that accounted for gender-based discrimination. Second, the Court emphasized 'that gender stereotypes are incompatible with international human rights law,' while also arguing that 'motherhood is an essential part of the free development of a woman's personality' in order to develop a violation of the right to private life (Artavia Murillo et al. v. Costa Rica 2012). By simultaneously rejecting and relying on gender stereotyping to develop its reasoning in this case, the Court revealed an uncomfortable tension in how it defines and locates violations of women's reproductive rights within the women's rights framework.

Case 3: Velásquez Paiz et al. v. Guatemala (2016) 
This case included an in-depth analysis of the impact of gender stereotyping on violence against women and resulted in reparation measures designed to address systemic gender discrimination. The case involved Claudia Velásquez Paiz, a young law student, who was murdered by a non-state actor. The Guatemalan State failed to adequately investigate the crime, and in their petition, the victim's representatives asserted that the murder of women in Guatemala was not random, and was 'founded on a patriarchal construct of a woman's sexual body being men's property' (Velásquez Paiz et al. v. Guatemala 2013). The petitioner determined that 'the system of oppression [was] built through violence against [women's] bodies and sexuality.' The impact of gender stereotyping as it affects violence perpetrated against women was explored exhaustively in the Court judgment. For example, in examining violations of Articles 1 and 24 of the ACHR, which deal with principles of equality and nondiscrimination, the Court determined that the subordination of women is based on gender stereotypes, and that 'their creation and use becomes one of the causes and consequences of gender violence against women' (Velásquez Paiz et al. v. Guatemala 2016). The Court went so far as to note that violence against women is aggravated 'when reflected, implicitly or explicitly, in policy and practice, particularly in the reasoning and language of state authorities.' In regards to the Convention of Belém do Pará, the Court examined Articles 7(b) and 7(c) to determine that the State of Guatemala had failed in its obligation to provide due diligence to the victim, and to women in general.

Finally, the reparations issued in this case have significant potential in their capacity to transform the lives of women and girls in Guatemala. Notably, the Court included the following guarantee of non-repetition:

The Court orders the State, within a reasonable time, to incorporate within the National Education System curriculum, at all levels, a permanent education program on the need to eradicate gender-based discrimination, gender stereotypes and violence against women in Guatemala, in light of the international standards on these matters and the jurisprudence of this Court. (Velásquez Paiz et al. v. Guatemala 2016, para 100)

The Court also called for training and education programs for the Guatemalan judiciary and police force. The reparations issued in this case undoubtedly set a standard for future women's rights cases.

\section{Case 4: IV v. Bolivia (2016)}

$I V$ v. Bolivia, is notable as the Court's second reproductive rights case, and the first reproductive rights case to incorporate the Convention of Belém do Pará. In this case, a migrant woman with limited economic means was sterilized without her consent after delivering her child. This case is particularly interesting because the Bolivian state's Ombuds Office represented IV; the first time that a state entity was permitted to raise a petition against its own state. In its analysis of the merits of this case, the Court determined that IV's intersecting characteristics as a poor, migrant, woman contributed to her mistreatment by medical doctors. The Court determined 'the State of Bolivia incurred a breach of its positive 
obligation to take measures to prevent and remedy discriminatory situations,' with reference to violations of Article 7(b), (c), (f) and (g) of the Convention of Belém do Pará (IV v. Bolivia 2016). Additionally, the Court examined the asymmetrical power imbalance between doctors and their patients, as well as provided an in-depth analysis of the right to informed consent.

In that this case included a violation of the Convention of Belém do Pará, the Court was able to issue reparations designed to address systemic gender discrimination. The Court concluded, 'reparations should include an analysis that contemplates not only the right of the victim to obtain reparation, but also incorporates a gender perspective, both in its formulation and in its implementation' (IV v. Bolivia 2016). To this end, the Court adopted expansive reparation measures designed to train medical professionals and students, and all personnel working in health and safety systems, on issues of informed consent, discrimination based on gender stereotypes, and gender violence (ibid.). This case successfully linked women's reproductive rights to the violence against women framework, and serves as an example for future litigation efforts that seek to effectively engender reproductive rights.

The brief case studies highlighted above reveal the inconsistent yet progressive nature of women's rights litigation in the IASHR. While there has been undeniable progress in terms of developing women's rights jurisprudence before the Court, sustainable application and protection of women's rights relies on the willingness of individual actors to engage in gendered analyses of women's rights violations. The Artavia Murillo et al. case provides a warning for future litigation efforts that fail to effectively incorporate a gender perspective, and the remaining three case studies highlight the potential power of the Convention of Belém do Pará.

\section{CONCLUSION}

As the Inter-American System of Human Rights continues to develop jurisprudence in the area of women's rights, it undoubtedly contributes to the feminist project of engendering human rights law. Not only is it important for the Commission and the Court to 'get it right' when it comes to protecting and fulfilling the human rights of women in the Americas, but because regional and international human rights bodies cross-pollinate and rely on each other to establish precedent (Shelton 1999), the IASHR must set a strong example for how to develop an effective women's rights agenda. There are currently a number of women's rights cases admitted to the Commission, each one bringing with it new opportunities to further define and repair violations of women's rights (Inter-American Commission on Human Rights n.d.c). This chapter concludes by introducing two strategic ways forward in women's rights litigation. While these suggestions are geared towards the IASHR, they can be applied in the context of other regional and international human rights monitoring bodies.

Linking Rights: Economic, Social and Cultural Rights and Women 
While the IASHR has proven its capacity, albeit inconsistent, to incorporate a gender perspective in women's rights litigation using the Convention of Belém do Pará, it has thus far failed to apply the Additional Protocol to the American Convention on Human Rights in the Area of Economic, Social, and Cultural Rights (Protocol of San Salvador) to women's rights cases. Recently the Court established its jurisdiction over the Protocol of San Salvador (the right to education), essentially paving the way for advocates and litigators engaged with the IASHR to begin framing women's rights violations using a multidimensional perspective, combining a focus on economic, social, cultural, civil and political rights (Lluy and Others $v$. Ecuador 2015). Such an approach would help to advance the women's rights agenda for several reasons.

First, the traditional hierarchical division of rights into generations of rights is not a useful way of articulating how rights interact (Feria Tinta 2007). For instance, in cases concerning women's reproductive health, it is impossible to separate the right to health (Protocol of San Salvador, art 10) from the right to life (ACHR, art 4) or the right to privacy (ACHR, art 11). Or, as Rosalind Petchesky contends, 'when we look at specific reproductive and sexual rights and the ways in which they cluster together with other rights in women's everyday lives [...] deciding whether to classify such rights as "social," "economic," "cultural," or also "civil and political” is very difficult' (Petchesky 2003). Second, the separation of human rights aligns with and subsequently substantiates the public/private divide (MacKinnon 2007). Typically, economic, social and cultural rights (ESCRs) have been considered to be less justiciable rights, existing in the private sphere, with little to no formal state regulation or protection, whereas civil and political rights are public rights, heavily regulated by the state, and considered entirely enforceable. Lastly, by upholding the division of rights, the IASHR allows states to escape their positive obligation to create and support economic, social, and cultural conditions in which rights are protected, promoted, and fulfilled. Looking forward, actors involved in the IASHR must look for opportunities to allege violations of provisions that are protected and justiciable within the Protocol of San Salvador: the right to education and the right to unionize. Only when women's rights violations are investigated using such a multifaceted lens will it be possible to effectively dissect and challenge 'deep-lying imbalances of power and social structures and practices of subordination that characterize relations between women and men in most societies' (Sifris 2010; Petchesky 2003).

\section{Gender-Based Reparations}

Finally, the IASHR operates a robust reparations mechanism, and as outlined above, the Commission and the Court have elected to issue reparation measures intended to redress gendered harm (ACHR, art 63). While reparations are a powerful way to repair individual, and at times structural violence and discrimination, women's rights litigators have failed to effectively and consistently pursue the reparation mechanism from a gender perspective. Despite the Court's declaration that reparations should take gender into account, there is no institutional process to ensure reparation measures are in fact gendered (González et al. $v$. Mexico 2009). To propagate a tradition of gender-based reparations in the IASHR, it is imperative that litigators provide the Commission and the Court every opportunity to delve 
into the gendered dynamics of women's rights violations. There are several ways to do this, including those discussed earlier in this chapter - feminist appropriation of the due diligence principle, increased engagement and collaboration with feminist civil society, and a multidimensional rights perspective that includes the Convention of Belém do Pará. However, the simultaneously easiest and most difficult way to advance a sustainable gender reparations tradition is to ensure that petitioners raising cases before the Commission and the Court are well-versed and knowledgeable about the role gender plays in women's rights violations. The above case study of Artavia Murillo et al. v. Costa Rica highlighted the necessity of treating women's rights as gender-specific rights, and provides a warning for future litigants who may prefer to avoid the gendered implications of human rights violations.

As the IASHR moves forward it faces opportunities to engage in women's rights cases addressing violations across a myriad of issues, including the right to abortion (Manuela v. El Salvador; AN v. Costa Rica; Aurora v. Costa Rica), violence against women (Linda Loaiza López Soto and Family v. Venezuela) and forced sterilization (FS v. Chile). Now that the Commission and the Court have issued decisions and judgments in a number of women's rights cases, it is imperative that actors engaged with the IASHR look back and learn from past litigation efforts. If recent case law is any indicator of what is to come, the IASHR is posed to continue leading the way in developing a progressive women's rights agenda.

\section{ACKNOWLEDGEMENTS}

Interviews with a number of experts conducted by the author in 2014 informed this chapter, including: Alejandra Cardenas, Deputy Director, Global Legal Program, Center for Reproductive Rights; Rosa Celorio, Attorney, Women's Rights Desk, Inter-American Commission on Human Rights; Rocío Pilar Puente Tolentino, Coordinator, Sexual and Reproductive Rights Program, Manuela Ramos; Liz Meléndez, Executive Director, Flora Tristan.

\section{REFERENCES}

Abi-Mershed EAH (2009) Due Diligence and the Fight against Gender-Based Violence in the Inter-American System. In: Benninger-Budel C (ed.) Due Diligence and Its Application to Protect Women from Violence. Leiden: Brill, 127-137.

Burbano-Herrera C (2010) Provisional Measures in the Case Law of the Inter-American Court of Human Rights. Antwerp: Intersentia.

Cardenas, A (2014) Interview with author. Washington, DC, 27 August.

Cavallaro J, Schaffer EJ (2004) Less as More: Rethinking Supranational Litigation of Economic and Social Rights in the Americas. Hastings L J 56(2): 217-282.

Celorio R (2014) Interview with author. Washington, DC, 28 August. 
Center for Reproductive Rights (2013) Despite Country's Own Laws, Costa Rica Continues to Deny Women Legal Abortion. Available at www.reproductiverights.org/pressroom/despite-country $\% \mathrm{E} 2 \% 80 \% 99 \mathrm{~s}$-own-laws-costa-rica-continues-to-deny-women- legalabortion.

Craske N, Molyneux M (2002) The Local, the Regional and the Global: Transforming the Politics of Rights. In: Craske N, Molyneux M (eds.) Gender and the Politics of Rights and Democracy in Latin America. London: Palgrave Macmillan, 1-31.

Crenshaw K (1991) Mapping the Margins: Intersectionality, Identity Politics, and Violence against Women of Color. Stanford L Rev 43(6): 1241-1299.

Feria Tinta M (2007) Justicability of Economic, Social and Cultural Rights in the Inter American System of Protection of Human Rights: Beyond Traditional Paradigms and Notions. Human Rts Q 29(2): 431-459.

García-Del Moral P, Dersnah MA (2014) A Feminist Challenge to the Gendered Politics of the Public/Private Divide: On Due Diligence, Domestic Violence, and Citizenship.

Citizenship Studies 18(6-7): 661-675.

Inter-American Commission on Human Rights (n.d.a) Hearings and Other Public Events: Rights of Women. Available at:

http://www.oas.org/es/cidh/audiencias/TopicsList.aspx?Lang=en\&Topic=15.

Inter-American Commission on Human Rights (n.d.b) Women - Judgments of the InterAmerican Court of Human Rights. Available at:

http://www.oas.org/en/iachr/women/decisions/ia_Court_HR.asp.

Inter-American Commission on Human Rights (n.d.c) Women - Reports on Petitions and Cases. Available at: http://www.oas.org/en/iachr/women/decisions/iachr.asp.

MacKinnon CA (2007) Are Women Human? And Other International Dialogues. Cambridge, MA: Harvard University Press.

Melendez L (2014) Interview with author. Lima, Peru, 9 July.

MESECVI (2012) Second Hemispheric Report on the Implementation of the Belém do Pará Convention. Organization of American States. Available at https://www.oas.org/en/mesecvi/docs/mesecvi-segundoinformehemisferico-en.pdf.

Mohanty CT (2003) Feminism without Borders: Decolonizing Theory, Practicing Solidarity. Durham: Duke University Press.

OAS (1969) American Convention on Human Rights. Available at www.oas.org/en/iachr/mandate/basic_documents.asp.

OAS (1999) Guidelines for Participation of Civil Society Organizations in OAS Activities. Available at www.oas.org/consejo/resolutions/res759.asp.

OAS (2009) Rules of Procedure of the Inter American Court of Human Rights (2009). 
Available at

www.cidh.oas.org/Basicos/English/Basic20.Rules\%20of\%20Procedure\%20of\%20the

$\% 20$ Court.htm.

OAS (2013) Rules of Procedure of the Inter-American Commission on Human Rights (2013). Available at www.oas.org/en/iachr/mandate/Basics/rulesiachr.asp.

OAS (n.d.a) Basic Documents in the Inter-American System. Available at www.oas.org/en/iachr/mandate/basic_documents.asp.

OAS (n.d.b) What We Do. Available at: www.oas.org/en/about/what_we _do.asp.

Puente Tolentino, RP (2014) Interview with author. Lima, Peru, 30 June.

Shelton D (1999) The Promise of Regional Human Rights Systems. In: Weston BH, Marks SP (eds.) The Future of International Human Rights. Leiden: Martinus Nijhoff.

Pasqualucci JM (2013) The Practice and Procedure of the Inter-American Court of Human Rights, $2^{\text {nd }}$ edn. New York: Cambridge University Press.

Petchesky R (2003) Global Prescriptions: Gendering Health and Human Rights. London: Zed Books.

Rapporteur on the Rights of Women (2011a) Access to Information on Reproductive Health from a Human Rights Perspective, Inter-American Commission on Human Rights, Organization of American States. Available at: www.oas.org/en/iachr/women/default.asp.

Rapporteur on the Rights of Women (2011b) Access to Justice for Women Victims of Sexual Violence, Inter-American Commission on Human Rights, Organization of American States. Available at: www.oas.org/en/iachr/women/default.asp.

Vargas V (2002) The Struggle by Latin American Feminisms for Rights and Autonomy. In: Craske N, Molyneux M (eds.) Gender and the Politics of Rights and Democracy in Latin America. London: Palgrave Macmillan, 199-221.

Zuloaga PP (2008) The Path to Gender Justice in the Inter-American Court of Human Rights. Texas J of Women \& L 17(2): 227-295.

\section{Law and Cases}

Artavia Murillo et al. ('In vitro fertilization') v. Costa Rica (2012) Inter-American Court of Human Rights (ser. C) No. 257 Preliminary Objections, Merits, Reparations and Costs.

Claudina Isabel Velásquez Paiz et al. v. Guatemala (2013) Inter-American Commission on Human Rights Report No. 53/1, Case 12.777 Merits.

FS v. Chile (2014) Inter-American Commission on Human Rights Petition 112-09, Report No. 52/14 Admissibility. 
González et al. ('Cotton Field') v. Mexico (2009) Inter-American Court of Human Rights (ser. C) No. 205, Preliminary Objection, Merits, Reparations, and Costs.

Available at: http://www.corteidh.or.cr/docs/casos/articulos/seriec_205_ing.pdf.

IV v. Bolivia (2016) Inter-American Court of Human Rights (ser. C) No. 329, Preliminary Objection, Merits, Reparations, and Costs.

Lluy and Others v. Ecuador (2015) Inter-American Court of Human Rights (ser. C) No. 298, Preliminary Exceptions, Merits, Reparations and Costs.

Linda Loaiza López Soto and Relatives v. Venezuela (2016) Inter-American Commission on Human Rights Case 12.797, Report No. 33/16, Submitted to Inter-American Court.

Manuela v. El Salvador (2017) Inter-American Commission on Human Rights Petition 42412, Report No. 29/17 Admissibility.

Velásquez Pais et al. v. Guatemala (2016) Inter-American Court of Human Rights (ser. C) No. 307 Preliminary Objection, Merits, Reparations and Costs. 